\title{
イネの病害応答に拈けるトレードオフの分子機構
}

\author{
高辻 博志 $1 *$
}

\begin{abstract}
TAKATSUJI, H. ${ }^{1 *}$ (2016). Molecular mechanisms of trade-offs in disease resistance of rice. Jpn. J. Phytopathol. 82: $289-295$.

Plants are continuously exposed to deleterious biotic and abiotic stresses. In rice, WRKY45 is a crucial transcription factor in the salicylic acid defense signaling pathway, on which several chemical-defense inducers act. We have developed transgenic rice lines using WRKY45 that are resistant to multiple diseases, and during that work, found that the extremely strong disease resistance that results from the overexpression of WRKY45 renders rice hypersensitive to low temperature and high salinity due to antagonistic crosstalk of defense signaling against abiotic stress signaling. Here, we introduce molecular mechanisms underlying the trade-off between disease resistance and abiotic stress responses, highlighting strategies involving crosstalk between signaling pathways.
\end{abstract}

(Received March 15, 2016; Accepted April 20, 2016)

Key words: Rice, Magnaporthe oryzae, low temperature, WRKY45, MAP kinase, tyrosine dephosphorylation, signaling crosstalk

\begin{abstract}
緒 言
みずから動くことの出来ない植物は, 環境からの様々な ストレスに絶えずさらされている. アミノ酸などのリソー スが限られた中でそのような状況に対処して生き延びるた め, 植物はその時々で生命の存続を最も強く脅かすストレ スに対してリッースを配分することにより,“トレードオフ” するメカニズムを進化の過程で獲得している，また，ス卜 レス応答反応は, 光合成やタンパク質合成なぞ, 生命維持 や生長に必要な機能などともトレードオフの関係にある. これらのトレードオフは, しばしば複数のシグナル伝達経 路のクロストークによって制御されているが，その分子メ カニズムについては核とんぞわかっていない，筆者らは， サリチル酸経路を介した誘導抵抗性を研究する中で, 病害 応答, 環境応答, 生育の間のトレードオフに関わる様々な 現象に遭遇した。本稿では, これらの現象の概要と一部明 らかになった分子メカニズムについて概説する.

病害応答シグナル伝達に打けるサリチル酸経路は, 初期 にはタバコ (Nicotiana tabacum) やシロイヌナズナ
\end{abstract} (Arabidopsis thaliana) を中心に研究されてきた. シロイヌ ナズナのサリチル酸経路では, 転写因子のコファクターで
あるNPR1が主要な役割を担っている.イネ（Oryzae sativa）では, 研究の初期段階に打いてサリチル酸経路の重 要性が疑問視されたが, 現在ではイネでもサリチル酸経路 の重要性が認識されている. 筆者らは, イネのサリチル酸 経路が, NPR1 のオーソログである OsNPR1 と転写因子 WRKY45 とがそれぞれ制御する二つの経路に分岐し，それ ぞれが異なる役割を担っていることを提唱している（第 1 図) (Nakayama et al., 2013; Shimono et al., 2007; Sugano et al., 2010; Takatsuji et al., 2010).WRKY45 は，その遺伝子がサリ チル酸経路に作用する抵抗性誘導剂（Plant activator）であ るベンゾチアジアゾール (BTH) やプロベナゾール, チア ニジルなどによって転写誘導され，これらの抵抗性誘導剤 の病害防除作用に必須の役割を担っている (Shimono et al., 2007; Shimono et al., 2012)．また，WRKY45 の過剩発現イネ は，糸状菌病であるいもち病 (Magnaporthe oryzae) 拉よび ごま葉枯病 (Cochliobolus miyabeanus) や細菌病である白葉 枯病 (Xanthomonas oryzae, pv. oryzae) に強い抵抗性を示す (Shimono et al., 2007; Shimono et al., 2012)．WRKY45 の下流 にはWRKY62 などいくつかの転写因子が制御されて和り, 転写因子のカスケードが構成されている (Nakayama et al., 2013)。WRKY45 の制御に関しては, 転写レベルで自己制御

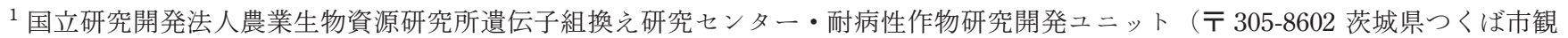
音台 2-1-2） National Institute of Agrobiological Sciences, 2-1-2 Kannondai, Tsukuba, Ibaraki 305-8602, Japan

*Corresponding author (E-mail: takatsuh@affrc.go.jp)
} 


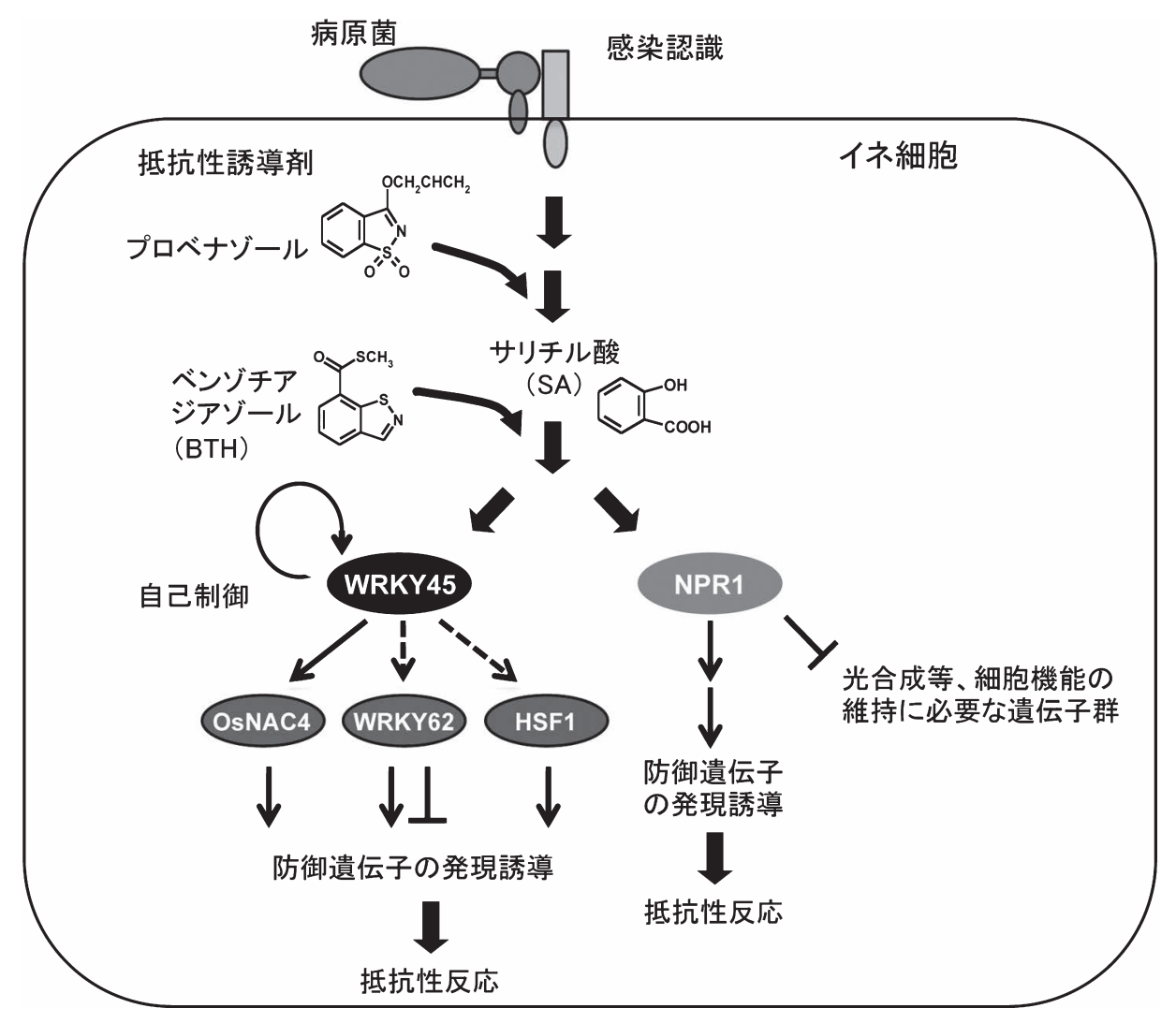

第 1 困 イネのサリチル酸経路と抵抗性誘導剤の作用

していること（Nakayama et al., 2013)， ユビキチンープロテ アソーム分解によってデュアル制御されていること (Matsushita et al., 2013)，サリチル酸応答性の MAP キナー ゼによってリン酸化されること（Ueno et al., 2013), NB-LRR タンパク質である $\mathrm{Pb} 1$ の機能発現機構にも関わっているこ と (Inoue et al., 2013) などがわかっている.さらに, WRKY45を介した防御反応はサリチル酸経路とサイトカイ ニン経路の二つのシグナル伝達経路の相乗作用によって制 御されて扣り，これらが抵抗性誘導剤の作用に見られる“プ ライミング効果”の基礎をなしていることが示唆されてい る (Akagi et al., 2014; Jiang et al., 2013).

\section{WRKY45 過剩発現イネに対する環境因子の影響}

強い恒常的活性を有するトウモロコシのユビキチンプロ モーターを用いた WRKY45 過剩発現イネ $\left(\mathrm{P}_{Z m U b i}\right)$ は，系状 菌抏よび細菌に対して非常に強い複合抵抗性を示す一方で, 生育や収量などの農業形質に問題があり，その程度はイネ の生育環境にも影響される (Shimono et al., 2007). 筆者らは, WRKY45 の発現による複合病害抵抗性の実用化のため, WRKY45 の転写に用いるプロモーターを最適化する研究を 行った. そのための一つのストラテジーとして，恒常的な
発現のレベルを最適化することで強い複合抵抗性と良好な 生育・収量の両立を図ることにした，イネ由来の 16 種の恒 常性プロモーターを用いて多数の形質転換系統を作製し, 複合病害抵抗性の検定および野外隔離䚾場での生育・収量 調査を経て，最適のコンストラクト $\left(\mathrm{P}_{O s U b i 7}\right)$ による系統を 選抜した（Goto et al., 2015; Takatsuji, 2014）。 その過程に特 いて，WRKY45 過剰発現イネの農業形質に低温が悪影響を 及ぼすことが示唆された。そこで低温の影響を詳細に調べ るため, 非形質転換日本晴および WRKY45 導入系統を低温 $\left(8^{\circ} \mathrm{C}\right)$ で 7 日間処理した後，通常の温室に戻し，7日後の 生存率を調べたところ, 非形質転換日本晴がすべて回復し たのに対し， $\mathrm{P}_{Z m U b i}$ 系統の $80 \%$ 以上が枯死した。 このこと から，WRKY45 の過剩発現によってイネが低温に対して高 感受性になることがわかった（Goto et al., 2015）。次に，耐 性機構の上で低温との関係が深い環境因子である高塩濃度 についても同様の実験を行った. $250 \mathrm{mM} \mathrm{NaCl}$ で 10 日間灌 水した後, 水で 7 日間灌水した後の生存率を調べた結果, 非形質転換日本晴の生存率が $75 \%$ であるのに対して， $\mathrm{P}_{Z m U b i}$ 系統は 0-13\%であり，WRKY45 の過剩発現によってイネは 高塩濃度に対しても高感受性になることがわかった。これ らの現象は, 病害抵抗性を強化した結果, 低温や高塩濃度 
などの環境ストレス耐性が犠牲になるといらトレードオフ の結果と考兄られる。な拈, $\mathrm{P}_{\mathrm{OsUbi}}$ 系統は, 低温, 高塩濃度 のいずれに対しても生存率が非形質転換日本晴と同等であ り, WRKY45 発現レベルの最適化によってこのトレードオ フの問題が解決されていることがわかった (Goto et al., 2015).

なお，WRKY45 の実用化に関しては，上記以外に，感染 応答性プロモーターと翻訳エンハンサーを組合せることに より，収量特性に悪影響を与えずにさらに強い複合抵抗性 を与えることに成功している (Goto et al., 2016).

\section{OsNPR1 による病害応答と光合成の間のトレードオフ}

OsNPR1 は, WRKY45 とともに抵抗性誘導剂の病害防除 作用に必須の因子である (Sugano et al., 2010). BTH 処理し た OsNPR1ノックダウンイネを用いたマイクロアレイから， 病害抵抗性と生命維持や生育との間のトレードオフにかか わる興味深い事実が明らかになった。 BTH応答性であり WRKY45 に発現が依存している遺伝子は転写誘導がほとん ぞであったのに対し (Nakayama et al., 2013), BTH 応答性 で OsNPR1 に依存している遺伝子には, 転写誘導される防 御関連遺伝子も多数含まれるものの, むしろ転写抑制され る遺伝子がより多数を占めていた（Sugano et al., 2010). そ れらの遺伝子には, 光合成の明反応抒よび暗反応にかかわ る遺伝子拉よび $30 \mathrm{~S}$ や $50 \mathrm{~S}$ のリボソームの遺伝子など葉緑 体のタンパク質合成にかかわる遺伝子が非常に多く含まれ， このカテゴリーに属する遺伝子のほとんどが OsNPR1 に依 存してBTH 処理によって抑制されることが明らかになった (第 1 表)。一方で，興味深いことに，40S や $60 \mathrm{~S}$ のリボソー ム等, 細胞質のタンパク質合成関連遺伝子の発現は, 逆に OsNPR1 依存的にBTH によって誘導されていた（第 1 表）。 このことから, BTH 処理が実際に光合成に及ぼす影響とそ の OsNPR1 依存性を確かめるため, 各処理後の植物体の葉 に打洸合成活性のパラメーター（Fv/Fm）を調べた（第 2 図)（Sugano et al., 2010）。その結果, 日本晴イネにおいて, BTH 処理により Fv/Fm が経時的に顕著に減少することがわ かった. 一方, OsNPR1ノックダウンイネではその減少が 緩やかであった. このことは, BTH 処理によって光合成活 性が低下することを示すとともに，その低下が OsNPR1 に 依存していることを示している. この現象は, 病原体感染 後の抵抗性誘導の間は, 光合成や葉緑体でのタンパク質合 成などの八ウスキーピング機能を一時的に停止し，代わり に細胞質でのタンパク質合成を活性化させ, PR タンパク質 合成などの防御反応にアミノ酸等のリソースが供給される ことを意味すると考兄られる。つまり病害応答と光合成と

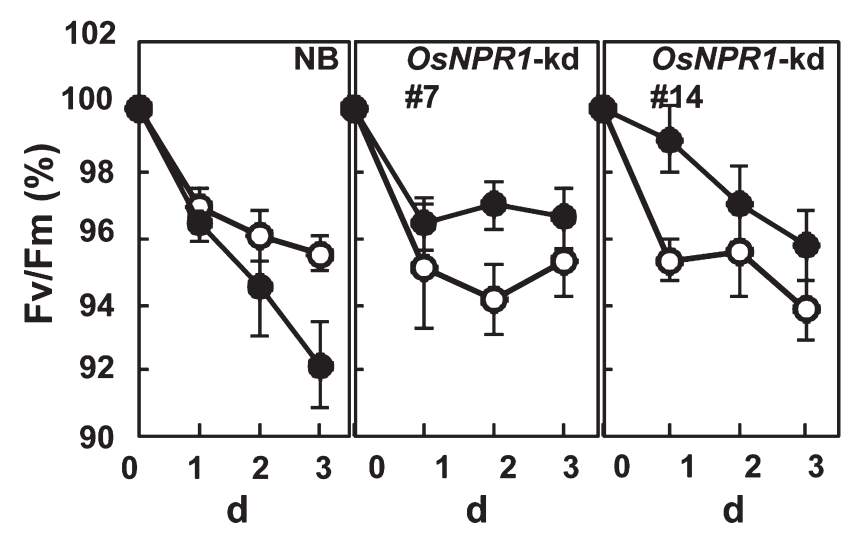

第 2 図葉の PSII 最大量子収率 ( Fv/Fm) 飞対する BTH の効 果と OsNPR1 ノックダウンの影響. 黒丸は BTH 処理, 白丸は mock 処理の值をそれぞれ示す. NB：野生型日 本晴イネ.

のトレードオフである．このことを見出した後，すでに報 告されていたシロイヌナズナの NPR1 依存的遺伝子発現の データ（Wang et al., 2006）を検証すると，シロイヌナズナ でも同様の制御が存在することがわかった. このよらに, NPR1 を介した防御応答と光合成との間のトレードオフは双 子葉植物と単子葉植物に共通らしい.

\section{3、 $\mathrm{ABA}$ を介した低温によるサリチル酸経路の抑制}

アブシジン酸（ABA）シグナリングは，低温，乾燥，高 塩濃度などの非生物学的ストレスに対する植物の応答に主 に関与しているが，病害応答の正または負の修飾因子でも ある (De Vleesschauwer et al., 2013; Takatsuji and Jiang, 2014)。サリチル酸経路に対しては，ABA は抑制的に作用 することにより病害応答を弱めることが報告された（Yasuda et al., 2008).

冷害年には，イネいもち病の被害が拡大寸ることが知ら れている，近年では，1993 年および 2003 年の冷害年に，そ

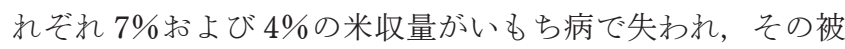
害額は 500-1000 億円に及ぶ. 古賀らは, ABA 処理によっ てイネのいもち病䍜病性が高まることを示し, 低温によっ て上昇する ABAがいもち病罹病性克進に関与していること を示唆した（Koga et al., 2004）。 また筆者らは，ABA シグナ ル伝達が SA シグナル伝達に及涪す拮抗作用に着目し，イネ でも ABA が SA 経路を抑制することを示した（Jiang et al., 2010)。また，この拮抗作用はWRKY45 打よび OsNPR1の 過剩発現によってそ文杂部分的に回復することから， $\mathrm{ABA}$ シグナルは SA 経路中の WRKY45 や OsNPR1 の上流に 作用することが明らかになった (Jiang et al., 2010; Yazawa et $a l ., 2012)$. WRKY 型転写因子は, MAP キナーゼなどのタン 
第 1 表 BTH による光合成およびタンパク質合成遺伝子の OsNPR1 依存的制御（抜粋）

\begin{tabular}{|c|c|c|c|c|}
\hline Locus ID & $\begin{array}{c}\text { Fold change } \\
\text { (BTH/mock } \\
\text { in WT) }\end{array}$ & $\begin{array}{l}\text { Fold change } \\
(\mathrm{BTH} / \mathrm{mock} \text { in } \\
\text { OsNPR1-kd) }\end{array}$ & $\begin{array}{c}\text { Fold change } \\
{[\mathrm{WT}(\mathrm{BTH}) /} \\
\text { OsNPR1-kd (BTH)] }\end{array}$ & Description \\
\hline \multicolumn{5}{|l|}{ 光合成 } \\
\hline Os04g0457000 & 0.14 & 0.91 & 0.22 & Chlorophyll a/b-binding protein CP24 \\
\hline Os07g0558400 & 0.21 & 0.78 & 0.36 & Chlorophyll a/b-binding protein CP29 precursor \\
\hline Os06g0320500 & 0.30 & 0.75 & 0.41 & Chlorophyll a/b-binding protein \\
\hline Os09g0439500 & 0.12 & 0.79 & 0.35 & Chlorophyll a/b-binding protein family protein \\
\hline Os07g0577600 & 0.17 & 0.75 & 0.21 & Lhca 2 protein \\
\hline Os08g0435900 & 0.16 & 0.74 & 0.20 & $\begin{array}{l}\text { Lhca4 protein, Type } 4 \text { protein of light-harvesting complex of } \\
\text { photosystem I precursor }\end{array}$ \\
\hline Os07g0544800 & 0.27 & 0.75 & 0.31 & Oxygen-evolving enhancer protein $3-2$, chloroplast precursor (OEE3) \\
\hline Os08g0560900 & 0.28 & 0.71 & 0.34 & Photosystem I reaction center subunit II, chloroplast precursor \\
\hline Os07g0148900 & 0.24 & 0.83 & 0.26 & Photosystem I reaction center subunit psaK, chloroplast precursor \\
\hline Os09g0481200 & 0.22 & 0.95 & 0.23 & Photosystem I reaction center subunit V (PSI-G) \\
\hline Os05g0560000 & 0.19 & 0.61 & 0.26 & $\begin{array}{l}\text { Photosystem I reaction center subunit VI, chloroplast precursor } \\
\text { (PSI-H) }\end{array}$ \\
\hline Os07g0105600 & 0.26 & 0.74 & 0.38 & Photosystem II oxygen evolving complex protein PsbQ family protein \\
\hline Os02g0578400 & 0.14 & 0.56 & 0.43 & Photosystem II oxygen evolving complex protein PsbQ family protein \\
\hline Os03g0343900 & 0.15 & 0.93 & 0.22 & Photosystem II protein PsbX family protein \\
\hline Os12g0291400 & 0.079 & 1.19 & 0.41 & Ribulose 1,5-bisphosphate carboxylase small subunit \\
\hline \multicolumn{5}{|l|}{ タンパク質合成 } \\
\hline Os07g0207400 & 2.80 & 1.60 & 1.80 & $40 \mathrm{~S}$ ribosomal protein $\mathrm{S} 2$ \\
\hline Os02g0105900 & 2.66 & 1.47 & 1.53 & $40 \mathrm{~S}$ ribosomal protein $\mathrm{S} 4$ \\
\hline Os07g0616600 & 2.47 & 1.49 & 1.68 & $40 \mathrm{~S}$ ribosomal protein SA \\
\hline Os04g0598200 & 2.13 & 1.33 & 1.44 & 60 S ribosomal protein L12 \\
\hline Os08g0156800 & 2.23 & 1.49 & 1.66 & 60 S ribosomal protein $\mathrm{L} 34$ \\
\hline Os09g0568400 & 2.25 & 1.43 & 1.58 & 60 S ribosomal protein $\mathrm{L} 40$ \\
\hline Os07g0224000 & 2.06 & 1.44 & 1.58 & Ribosomal protein L24E family protein \\
\hline Os08g0542100 & 2.13 & 1.23 & 1.53 & Ribosomal protein L30 family protein \\
\hline Os02g0111700 & 2.12 & 1.36 & 1.53 & Ribosomal protein L37e family protein \\
\hline Os03g0452300 & 0.32 & 0.71 & 0.61 & 30 S ribosomal protein S5 \\
\hline Os03g0843400 & 0.30 & 0.80 & 0.51 & 30S ribosomal protein $\mathrm{S} 6$, chloroplast precursor \\
\hline Os03g0704000 & 0.29 & 0.66 & 0.47 & 30 S ribosomal protein S13, chloroplast precursor \\
\hline Os03g0265400 & 0.29 & 0.63 & 0.53 & 50S ribosomal protein L4, chloroplast precursor \\
\hline Os03g0125000 & 0.31 & 0.78 & 0.52 & 50S ribosomal protein L5, chloroplast precursor \\
\hline Os01g0805000 & 0.22 & 0.71 & 0.38 & 50S ribosomal protein L34 \\
\hline Os03g0284400 & 0.29 & 0.75 & 0.44 & Ribosomal protein L10-like \\
\hline Os03g0356300 & 0.30 & 0.79 & 0.54 & Ribosomal protein L6 family protein \\
\hline Os01g0678600 & 0.28 & 0.72 & 0.42 & Ribosomal protein S20 family protein \\
\hline Os03g0271100 & 0.29 & 0.71 & 0.39 & Sigma factor SIG2B \\
\hline Os08g0242800 & 0.44 & 0.76 & 0.44 & Sigma factor SIG6 \\
\hline
\end{tabular}

パク質リン酸化酵素によってリン酸化されることにより， 活性化される例がいくつか知られている (Ishihama et al., 2011; Mao et al., 2011). また, MAPキナーゼはフォスファター ゼによる脱リン酸化によって不活性する（Anderson et al., 2011; Oka et al., 2013). WRKY45 は，サリチル酸経路中で活 性化した MAP キナーゼカスケード（OsMKK10-2-OsMPK6） によってリン酸化されることにより活性化することが明ら かになった（第 3 図 A）（Ueno et al., 2013）。また，この制
御を巡って防御応答と低温などの環境ストレスに対する応 答の間にトレードオフが存在し，そのメカニズムが以下の ように明らかになった（Ueno et al., 2015)。恒常的活性型 OsMKK10-2 をデキサメタゾン誘導的に発現させた形質転換 イネに拈いて，TEY モチーフのチロシン拈びトレオニン がリン酸化されて活性化したOsMPK6 は，ABA 処理により チロシン残基から脱リン酸化されて不活性化した（第 3 図 B)。また，タンパク質チロシン脱リン酸化酵素（OsPTP1/2） 


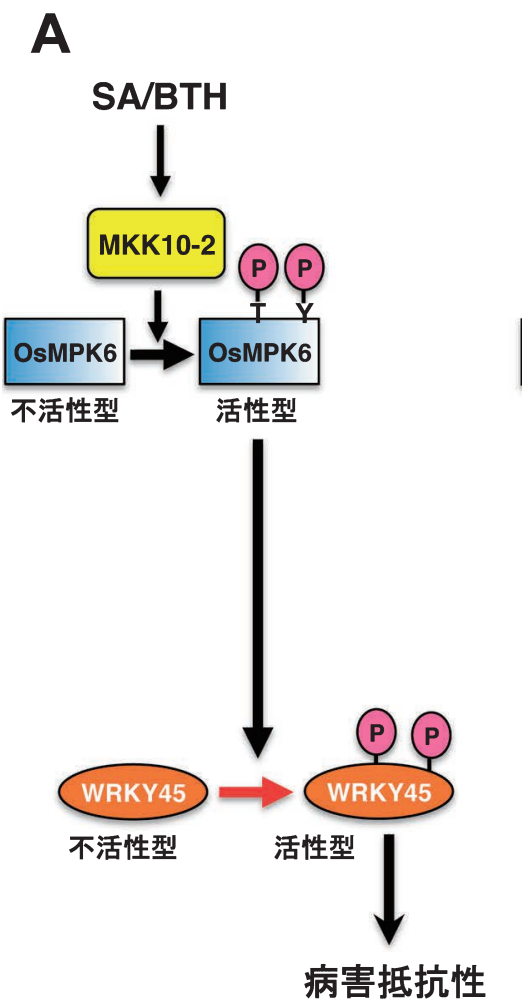

B

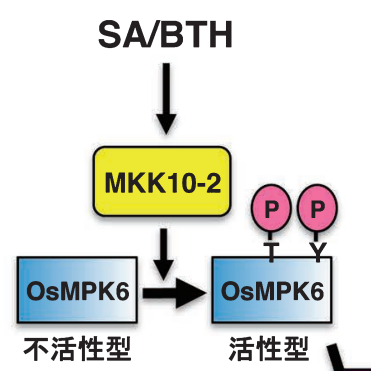

低温

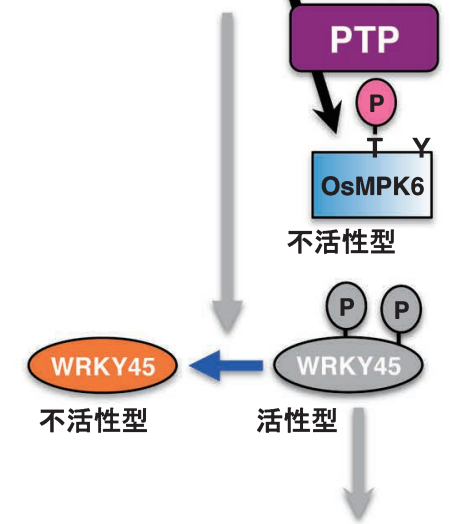

病害抵抗性

C

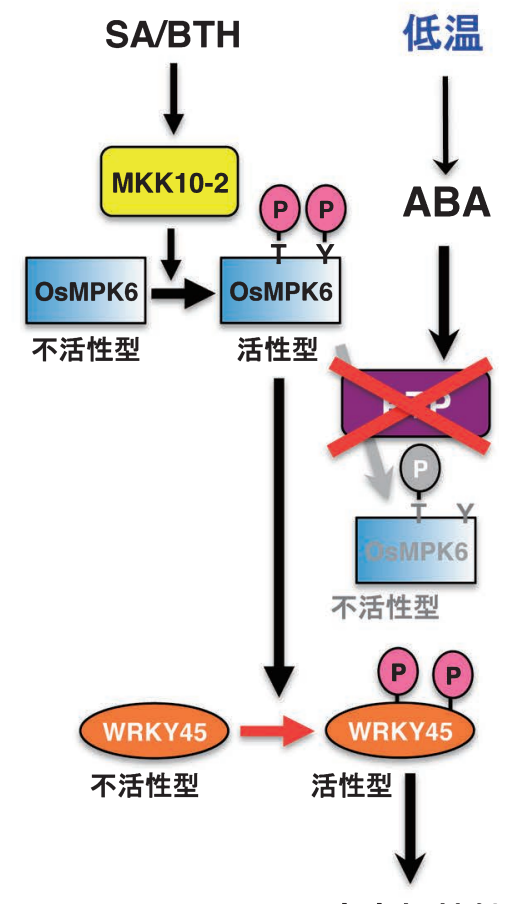

病害抵抗性

第 3 図 低温による誘導抵抗性低下の分子機構

A. 野生型イネ / 常温. B. 野生型イネ/低温. C. PTPノックダウンイネ/低温.
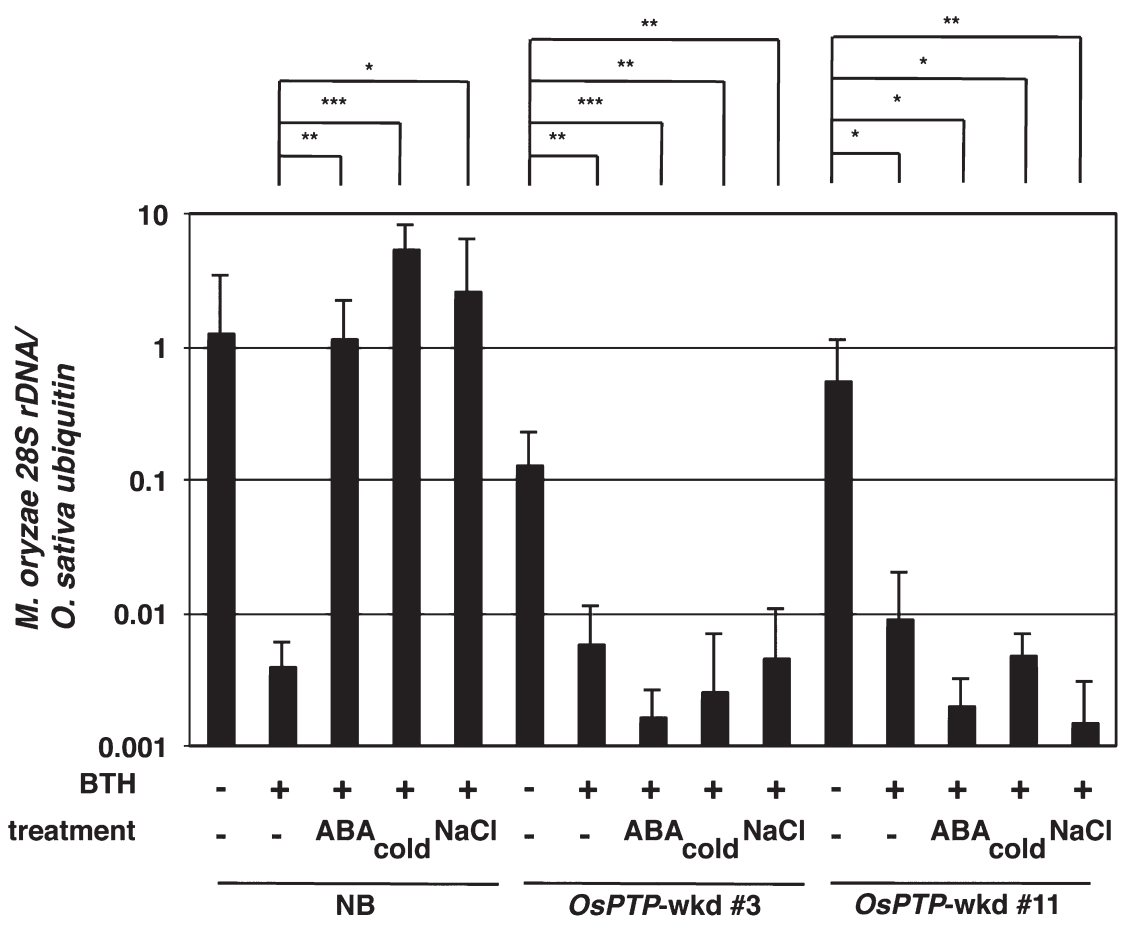

第 4 図誘導抵抗性に対する ABA と環境ストレスの影響，およびそれらに対する OsPTPノックダウンの効果.

日本晴イネ（NB）では，BTHによるいもち病に対する誘導抵抗性が ABA 処理または低温や高塩濃度などの環境ストレス によって低下したが，OsPTP1 および 2 を同時にノックダウンしたイネ系統（OsPTP-wkd \#3，\#11）では，これらの処理に よってBTHによる誘導抵抗性は影響を受けなかった。 *, $\mathrm{P}<0.1$; **, $\mathrm{P}<0.02$; ***, $\mathrm{P}<0.002$ (Student’s $t$-test). 
の遺伝子ノックダウンイネではABA による OsMPK6 のチ ロシン脱リン酸化が起こらなくなっていたことから（第 3 図 C), OsMPK6 のチロシン脱リン酸化反応は OsPTP1/2 に よるものであることがわかった。そこで， BTHによるいも ち病抵抗性の誘導に対する OsPTP $1 / 2$ ノックダウンの影響 を調べたところ, 日本晴イネではBTHによるいもち病抵抗 性誘導が ABA によって抑制されるのに対し, OsPTP1/2ノッ クダウンイネでは ABA によるいもち病抵抗性誘導の抑制が 䚾とんど見られなかった（第 4 図）。また，日本晴イネでは， 低温によっても BTH によるいもち病抵抗性誘導が抑制され るのに対し，OsPTP1/2ノックダウンイネではほとんど抑制 されなかった（第 4 図）。これらのメカニズムは，冷夏に拉 けるいもち病被害が拡大する現象と密接に関係していると

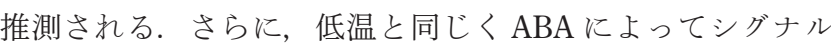
伝達される高塩濃度処理に打いても同様の結果となった（第 4 図)。これらの結果から, 誘導抵抗性の抑制は, ABAを介 したシグナル伝達によって媒介される環境ストレスに共通 のものである可能性が示唆された.

\section{終わりに}

植物に抢いて, 病害応答, 環境応答, 生命維持・生育の 三者の間に見られるトレードオフの関係がいくつか明らか になり，その分子機構の一部が明らかになった。植物はな ぜこのような仕組みを進化の過程で獲得したのであろら か? 颃そらく，貧栄養でリソースが限られた㛜しい自然条 件のもとで様々なストレスにさらされながら植物が生き延 びるには，このような仕組みが必要であったと想像される. 一方，農業に打ける人工栽培の場合は，肥料を十分に供給 することでリソースを補えるので，このような仕組みはむ しろ収量の上限を決定してしまう要因になる。OsPTP 遺伝 子を抑制することにより，低温や高塩濃度下でも誘導抵抗 性が効果的に発揮されることは, 人間に不都合な作物のト レードオフを改良できることを示している，同様のことが 他のトレードオフにもあてはまる可能性があり，今後の植 物科学や作物育種の一つの方向性を示していると考える.

\section{謝辞}

本研究は，霜野真幸，姜 昌杰，菅野正治，後藤新悟，井 上晴彦, 松下 茜, 上野宜久, 吉田理一郎, 赤城 文, 下田 一笹倉芙裕子，福島説子，矢澤克美ら各氏と行ったものであ る. この研究は, 農林水産省新農業展開ゲノムプロジェク ト GMA0001 および PMI0008, 次世代ゲノム基盤プロジェ クトGM00006の支援を受けて行った.

\section{引用文献}

Akagi, A., Fukushima, S., Okada, K., Jiang, C.-J., Yoshida, R., Nakayama, A., Shimono, M., Sugano, S., Yamane, H. and Takatsuji, H. (2014). WRKY45-dependent priming of diterpenoid phytoalexin biosynthesis in rice and the role of cytokinin in triggering the reaction. Plant Mol. Biol. 86: 171-183.

Anderson, J.C., Bartels, S., Besteiro, M.A., Shahollari, B., Ulm, R. and Peck, S.C. (2011). Arabidopsis MAP Kinase Phosphatase 1 (AtMKP1) negatively regulates MPK6-mediated PAMP responses and resistance against bacteria. Plant J. 67: 258-268.

De Vleesschauwer, D., Gheysen, G. and Höfte, M. (2013). Hormone defense networking in rice: tales from a different world. Trends Plant Sci. 18: 555-565.

Goto, S., Sasakura-Shimoda, F., Suetsugu, M., Selvaraj, M.G., Hayashi, N., Yamazaki, M., Ishitani, M., Shimono, M., Sugano, S., Matsushita, A., Tanabata, T. and Takatsuji, H. (2015). Development of disease-resistant rice by optimized expression of WRKY45. Plant Biotechnol. J. 13: 753-765.

Goto, S., Sasakura-Shimoda, F., Yamazaki, M., Hayashi, N., Suetsugu, M., Ochiai, H. and Takatsuji, H. (2016). Development of diseaseresistant rice by pathogen-responsive expression of WRKY45. Plant Biotechnol. J. 14: 1127-1138.

Inoue, H., Hayashi, N., Matsushita, A., Xinqiong, L., Nakayama, A., Sugano, S., Jiang, C.J. and Takatsuji, H. (2013). Blast resistance of CC-NB-LRR protein $\mathrm{Pb} 1$ is mediated by WRKY45 through protein-protein interaction. Proc. Natl. Acad. Sci. USA 110: 9577-9582.

Ishihama, N., Yamada, R., Yoshioka, M., Katou, S. and Yoshioka, H. (2011). Phosphorylation of the Nicotiana benthamiana WRKY8 transcription factor by MAPK functions in the defense response. Plant Cell 23: 1153-1170.

Jiang, C.-J., Shimono, M., Sugano, S., Kojima, M., Yazawa, K., Yoshida, R., Inoue, H., Hayashi, N., Sakakibara, H. and Takatsuji, H. (2010). Abscisic acid interacts antagonistically with salicylic acid signaling pathway in rice-Magnaporthe grisea interaction. Mol. Plant-Microbe Interact. 23: 791-798.

Jiang, C.J., Shimono, M., Sugano, S., Kojima, M., Liu, X., Inoue, H., Sakakibara, H. and Takatsuji, H. (2013). Cytokinins act synergistically with salicylic acid to activate defense gene expression in rice. Mol. Plant-Microbe Interact. 26: 287-296.

Koga, H., Dohi, K. and Mori, M. (2004). Abscisic acid and low temperatures suppress the whole plant-specific resistance reaction of rice plants to the infection of Magnaporthe grisea. Physiol. Mol. Plant Pathol. 65: 3-9.

Mao, G., Meng, X., Liu, Y., Zheng, Z., Chen, Z. and Zhang, S. (2011). Phosphorylation of a WRKY transcription factor by two pathogenresponsive MAPKs drives phytoalexin biosynthesis in Arabidopsis. Plant Cell 23: 1639-1653.

Matsushita, A., Inoue, H., Goto, S., Nakayama, A., Sugano, S., Hayashi, N. and Takatsuji, H. (2013). The nuclear ubiquitin proteasome degradation affects WRKY45 function in the rice defense program. Plant J. 73: 302-313.

Nakayama, A., Fukushima, S., Goto, S., Matsushita, A., Shimono, M., Sugano, S., Jiang, C.J., Akagi, A., Yamazaki, M., Inoue, H. and Takatsuji, H. (2013). Genome-wide identification of WRKY45- 
regulated genes that mediate benzothiadiazole-induced defense responses in rice. BMC Plant Biol. 13: 150-160.

Oka, K., Amano, Y., Katou, S., Seo, S., Kawazu, K., Mochizuki, A., Kuchitsu, K. and Mitsuhara, I. (2013). Tobacco MAP kinase phosphatase (NtMKP1) negatively regulates wound response and induced resistance against necrotrophic pathogens and lepidopteran herbivores. Mol. Plant-Microbe Interact. 26: 668-675.

Shimono, M., Sugano, S., Nakayama, A., Jiang, C.J., Ono, K., Toki, S. and Takatsuji, H. (2007). Rice WRKY45 plays a crucial role in benzothiadiazole-inducible blast resistance. Plant Cell 19: 2064-2076.

Shimono, M., Koga, H., Akagi, A., Hayashi, N., Goto, S., Sawada, M., Kurihara, T., Matsushita, A., Sugano, S., Jiang, C.J., Kaku, H., Inoue, H. and Takatsuji, H. (2012). Rice WRKY45 plays important roles in fungal and bacterial disease resistance. Mol. Plant Pathol. 13: 83-94.

Sugano, S., Jiang, C.-J., Miyazawa, S.-I., Masumoto, C., Yazawa, K., Hayashi, N., Shimono, M., Nakayama, A., Miyao, M. and Takatsuji, H. (2010). Role of OsNPR1 in rice defense program as revealed by genome-wide expression analysis. Plant Mol. Biol. 74: 549562 .

Takatsuji, H., Jiang, C.-J. and Sugano, S. (2010). Salicylic acid signaling pathway in rice and the potential applications of its regulators. JARQ 44: 217-223.

Takatsuji, H. (2014). Development of disease-resistant rice using regulatory components of induced disease resistance. Front. Plant Sci. 5: 630.
Takatsuji, H. and Jiang, C.-J. (2014). Plant hormone crosstalks under biotic stresses. In Phytohormones: a window to metabolism, signaling and biotechnological applications (Tran, L.-S.P. and Pal, S., eds.). pp. 323-350, Springer, New York.

Ueno, Y., Yoshida, R., Kishi-Kaboshi, M., Matsushita, A., Jiang, C.J., Goto, S., Takahashi, A., Hirochika, H. and Takatsuji, H. (2013). MAP kinases phosphorylate rice WRKY45. Plant Signal. Behav. 8: e24510.

Ueno, Y., Yoshida, R., Kishi-Kaboshi, M., Matsushita, A., Jiang, C.J., Goto, S., Takahashi, A., Hirochika, H. and Takatsuji, H. (2015). Abiotic stresses antagonize the rice defence pathway through the tyrosine-dephosphorylation of OsMPK6. PLoS Pathog. 11: e1005231.

Wang, D., Amornsiripanitch, N. and Dong, X. (2006). A genomic approach to identify regulatory nodes in the transcriptional network of systemic acquired resistance in plants. PLoS Pathog. 2: e123.

Yasuda, M., Ishikawa, A., Jikumaru, Y., Seki, M., Umezawa, T., Asami, T., Maruyama-Nakashita, A., Kudo, T., Shinozaki, K., Yoshida, S. and Nakashita, H. (2008). Antagonistic interaction between systemic acquired resistance and the abscisic acidmediated abiotic stress response in Arabidopsis. Plant Cell 20: 1678-1692.

Yazawa, K., Jiang, C.-J., Kojima, M., Sakakibara, H. and Takatsuji, H. (2012). Reduction of abscisic acid levels or inhibition of abscisic acid signaling in rice during the early phase of Magnaporthe oryzae infection decreases its susceptibility to the fungus. Physiol. Mol. Plant Pathol. 78: 1-7. 